\title{
Analisis Bahan Ajar Membaca yang Tersedia Untuk Siswa Sekolah Dasar di Provinsi Bengkulu
}

\author{
Gumono \\ Program Magister (S2) Pendidikan Bahasa Indonesia FKIP UNIB \\ gumono@unib.ac.id
}

\begin{abstract}
The purpose of this research is to analyze the reading teaching materials available to elementary students in Bengkulu province. The research methods applied are quantitative descriptive. Data collection with survey techniques. Data analysis Results: 1. All available Indonesian reading material textbooks, according to the perception of the user's teacher, the quality is relatively high. 2. The weakness of the textbook are: $a$. The theme is presented less according to The characteristics of elementary school students in Bengkulu province. $b$. The presented material does not contain a student environment. $c$. The presented material is not student-centered. $d$. The material does not stimulate students to actively study independently. e. The concepts in these textbooks are lack in sequence.
\end{abstract}

Keywords: reading materials, elementary, Bengkulu

\section{Pendahuluan}

Pengajaran bahasa Indonesia pada semua jenjang pendidikan sampai saat ini diidentifikasi masih belum berhasil. Hasil penelitian kebijakan yang dibiayai oleh Balitbang Depdiknas menunjukkan bahwa dilihat dari tuntutan penggunaan bahasa Indonesia, kemahiran berbahasa Indonesia siswa SD dan SMP masih menampakkan berbagai kelemahan. (Suparno, Kurniawan, \& Widaryanto, 2016) Kesimpulan yang didapat dari penelitian tersebut terkait dengan kemahiran siswa pada empat keterampilan berbahasa. Kemahiran menyimak dan berbicara masih memprihatinkan dengan kualifikasi kurang hingga sedang.

Hal yang hampir sama juga ditunjukkan oleh kemahiran membaca dan kemahiran menulis siswa. Progress in International Reading Literacy Study (PIRLS) di dalam laporannya yang dirilis tahun 2016 memperlihatkan bahwa kemampuan membaca siswa kelas IV sekolah dasar masih tergolong rendah. Dengan mengutip hasil studi dari Vincent Greanary, dilaporkan bahwa siswa kelas enam SD Indonesia dengan nilai 51,7 berada di urutan paling akhir setelah Filipina $(52,6)$, Thailand $(65,1)$, Singapura $(74,0)$ dan Hongkong $(75,5)$. Kondisi ini terjadi, menurut penelitian tersebut, disebabkan oleh guru yang lebih banyak melaksanakan pembelajaran tentang bahasa dibanding dengan pembelajaran berbahasa.

Kondisi ini berkebalikan dengan saran Halliday (1975) yang menyatakan bahwa dalam pembelajaran bahasa seharusnya "siswa itu belajar berbahasa, belajar melalui bahasa, dan baru kemudian diikuti belajar tentang bahasa". Pengembangan bahasa pada anak memerlukan kesempatan menggunakan bahasa. Oleh karena itu, kita membutuhkan lingkungan pendidikan yang memberikan kesempatan yang banyak atau kaya bagi siswa untuk menggunakan bahasa di dalam cara-cara yang fungsional (Pinnel\& Matlin, 1990:2)

Pada proses belajar mengajar, guru yang memberi siswa kesempatan mengembangkan keterampilan berbahasa di dalam konteks nyata dan situasi yang kompleks, akan meningkatkan pembelajaran karena mereka (guru) memberi siswa 
pelatihan di dalam keterampilan yang terintegrasi dengan literasi tingkat tinggi. Komunikasi adalah inti pengajaran language arts, sementara itu tugas-tugas komunikasi yang kompleks adalah inti kemahirwacanaan tingkat tinggi (high literacy) (Council on Economic Development, 2011). Pada mulanya, di AS, literasi tingkat tinggi hanya merupakan tujuan pendidikan lembaga pendidikan elite, sementara lembaga pendidikan massal (pada umumnya) hanya mengarah pada literasi tingkat rendah. Dalam perkembangan selanjutnya, terkait dengan pertumbuhan masyarakat industri yang sangat tergantung pada informasi dan teknologi, standar literasi menjadi meningkat ke arah literasi tingkat tinggi. Oleh karena itu, guru language arts atau guru bahasa pada umumnya dituntut dapat meningkatkan literasi tingkat tinggi pada siswanya. Untuk mencapai tuntutan literasi tingkat tinggi tersebut langkah pengembangan literasi lintas kurikulum merupakan upaya realistis yang perlu terus diujicobakan (Resnick, 1987).

Selanjutnya, guru yang memberi pengalaman kepada siswa dengan pembelajaran terpadu melalui lingkungan mahir literasi (literate environment) ternyata dapat meningkatkan pembelajaran karena mereka (siswa) menggunakan proses-proses yang saling berkaitan antara membaca, menulis, berbicara, dan mendengarkan untuk komunikasi alamiah senyatanya (authentic commmunication) (Salinger, 2001). Lingkungan yang kaya bahan cetakan dan memberi kesempatan untuk menggunakannya akan mendorong siswa mengujicobakan dengan literasi. Siswa merasa membaca-menulis sebagai cara baru mengomunikasikan sesuatu yang berbeda dengan bahasa lisan. Mereka mengobservasi lingkungan cetakan (sumbersumber cetakan) dan "bermain" membaca dan menulis. Dengan cara ini mereka merasa bahwa literasi adalah bagian dari perkembangan alamiah mereka. Demikian juga, guru yang memahami bahwa membaca dan menulis berkembang secara simultan dapat membantu siswa menemukan kembali kemunculan keterampilan literasi di dalam sebuah konteks yang bermakna (Graves, 2011).

Kondisi empiris di sekolah-sekolah Indonesia memperlihatkan bahwa sebagian besar guru masih belum melaksanakan pembelajaran bahasa secara kreatif. Mereka umumnya masih mengandalkan sepenuhnya kegiatan pembelajaran bahasa Indonesia di kelas kepada buku teks. Hal ini antara lain disebabkan oleh kekurangmampuan guru menerjemahkan kurikulum ke dalam program pembelajaran (Trianto, Juli 1998,).

Sayangnya, berdasarkan pengamatan, bahan ajar bahasa Indonesia yang beredar pada umumnya tidak mengalami perubahan berarti meskipun kurikulum telah mengalami perubahan. Banyak dari buku tersebut yang hanya diberi label "sesuai dengan kurikulum (terbaru)" pada sampul buku, namun isinya tidak berubah secara bermakna. Intinya, materi pelajaran dalam buku teks yang beredar kurang menyebabkan siswa memahami teks dan kurang melatih siswa membuat berbagai teks untuk berbagai tujuan komunikasi.

Penelitian ini menganalisis bahan ajar/buku teks yang digunakan oleh siswa sekolah dasar yang ada di provinsi Bengkulu. Masalah yang dibahas dalam penelitian ini dirumuskan sebagai berikut. (1) Bagaimana persepsi guru tentang kelayakan buku teks yang tersedia di sekolah? (2) Bagaimana kelemahan buku teks yang tersedia menurut persepsi guru?

\section{Metode}

Penelitian ini menerapkan pendekatan penelitian kuantitatif dengan metode deskriptif. Mempertimbangkan tujuan penelitian, yakni menilai kelayakan bahan ajar yang tersedia di sekolah dasar, yang digunakan guru untuk mengajar keterampilan membaca, maka pada penelitian ini, guru menilai bahan ajar yang mereka gunakan menggunakan format penilaian disiapkan oleh peneliti. 
Partisipan penelitian ini adalah guru-guru yang mengajar mata pelajaran Bahasa Indonesia pada kelas 4 di Sekolah Dasar yang menjadi lokasi penelitian. Guru yang dilibatkan pada penelitian ini berasal dari 30 SD di tiga Kab./Kota di Provinsi Bengkulu.

Instrumen yang digunakan adalah angket "Persepsi Guru Terhadap Bahan Ajar Membaca Yang Digunakan Untuk Siswa Kelas 4 Sekolah Dasar Di Provinsi Bengkulu". Instrumen memuat penelitian memuat, yaitu: (1) Pendahuluan (kalimat pengantar untuk responden penelitian; (2) Petunjuk pengisian kuesioner; (3) Identitas bahan ajar yang digunakan; dan (4) Persepsi guru terhadap bahan ajar membaca yang digunakan.

Kuesioner persepsi disusun dalam rentang nilai 1 s.d. 4, mengukur empat aspek kelayakan, yakni: a) Kelayakan Isi, b) Kelayakan penyajian, c) Kelayakan Bahasa, dan d) Kelayakan perwajahan. Ada 32 pertanyaan terkait kelayakan pada empat aspek tersebut.

Instrumen telah diuji validitasnya dengan menghitung korelasi item total. Sementara Reliabilitas instrument diuji menggunakan formulas Alpha Cronbach. Pengumpulan data dilakukan dengan Teknik survey.

Analisis data dilakukan dengan menghitung rerata jawaban responden untuk masingmasing item. Hasil rerata kemudian dideskripsikan secara kualitatif.

Kriteria kelayakan:

$$
\begin{aligned}
& >0,80=\text { sangat rendah } \\
0,80 & -1,59=\text { rendah } \\
1,60-2,39= & \text { sedang } \\
2,40 \quad-3,19= & \text { tinggi } \\
3,19 \quad<\quad & =\text { sangat tinggi }
\end{aligned}
$$

\section{Hasil}

Bahan ajar yang digunakan guru dalam pembelajaran membaca di sekolah dasar di Provinsi Bengkulu adalah adalah buku teks bahasa Indonesia. Hal serupa juga berlaku di seluruh Indonesia. Berdasarkan observasi lapangan, ada tiga buku teks bahasa yang jumlah pemakainya cukup banyak. Tiga buku dimaksud adalah:

a) Judul Buku : Bahasa Indonesia 4

Pengarang : : Dian Sukmawati, Endang Rahmat, Deny Iskandar

Penerbit : $\quad$ CV Indradjaya (BSE Depdiknas)

Tahun terbit : 2010

Buku ini digunakan oleh 13 orang guru dari 30 sekolah dasar yang diamati. Guru yang memakai buku ini sebagai buku teks pelajaran umumnya menyatakan bahwa buku ini sudah cukup baik, namun perlu modifikasi oleh guru untuk mendapatkan hasil yang maksimal. Dengan memperhatikan kriteria kelayakannya, buku ini tingkat kelayakannya tergolong tinggi. Hanya ada beberapa sub komponen buku yang menurut persepsi guru, tergolong rendah. Berikut hasil lengkap persepsi guru terhadap buku "Bahasa Indonesia 4" yang terjaring melalui kuesioner yang disiapkan peneliti.

Tabel 1 Penilaian "Buku Teks Bahasa Indonesia 4" oleh Pengguna/Guru

\begin{tabular}{ccccc}
\hline $\begin{array}{c}\text { No } \\
.\end{array}$ & $\begin{array}{c}\text { Komponen/ sub } \\
\text { komponen }\end{array}$ & Detail & Rerata skor & Keterangan \\
\hline 1. & Kelayakan Isi & & & \\
\hline & $\begin{array}{l}\text { A. Kesesuaian } \\
\text { Materi dengan }\end{array}$ & 1) Keluasan Materi & 2,62 & Tinggi \\
\hline
\end{tabular}




\section{Gumono}

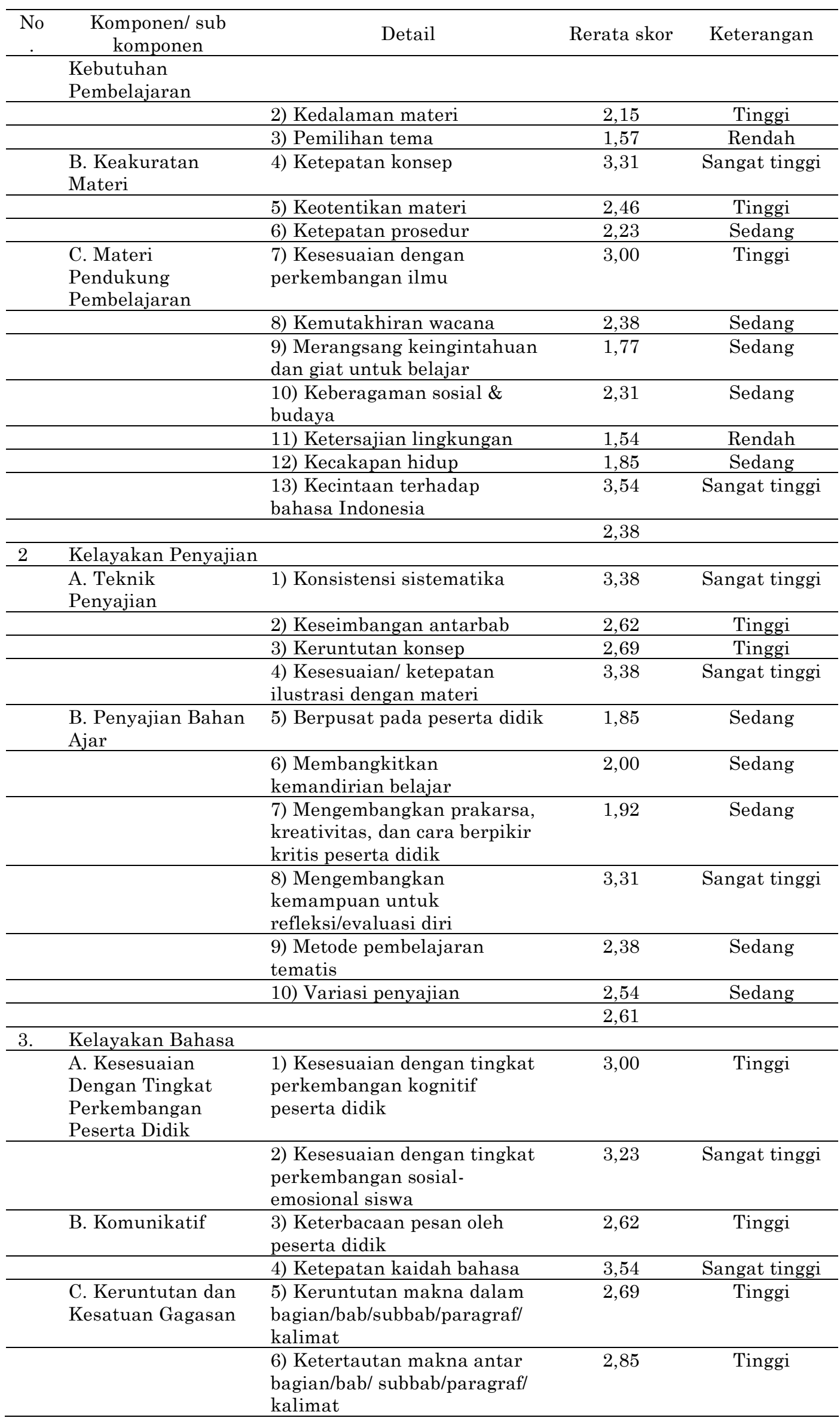




\begin{tabular}{|c|c|c|c|c|}
\hline No & $\begin{array}{c}\text { Komponen/sub } \\
\text { komponen }\end{array}$ & Detail & Rerata skor & Keterangan \\
\hline \multicolumn{5}{|c|}{2,99} \\
\hline 4. & \multicolumn{4}{|l|}{ Kelayakan Perwajahan } \\
\hline & \multirow[t]{2}{*}{$\begin{array}{l}\text { A. Tata Letak Isi } \\
\text { Buku }\end{array}$} & 1) Tata letak & 3,69 & Sangat Tinggi \\
\hline & & 2) Penggunaan Ilustrasi & 3,62 & Sangat Tinggi \\
\hline \multirow{2}{*}{\multicolumn{2}{|c|}{$\begin{array}{l}\text { B. Tipografi Isi } \\
\text { Buku }\end{array}$}} & 3) Tipografi & 3,69 & Sangat Tinggi \\
\hline & & & 3,67 & \\
\hline
\end{tabular}

Tabel 1 memperlihatkan bahwa secara keseluruhan, buku teks pelajaran bahasa Indonesia yang berjudul "Bahasa Indonesia 4" yang dikarang oleh Dian Sukmawati, Endang Rahmat, Deny Iskandar ini menurut persepsi guru tingkat kelayakannya tergolong tinggi.

Komponen isi/materi yang terdapat dalam buku ini sesuai dengan muatan standar kompetensi dan kompetensi dasar yang diisyaratkan kurikulum. Kelemahan buku ini menurut persepsi guru pengguna di Provinsi Bengkulu adalah pilihan tema dan ketersajian lingkungan. Menurut guru, tema yang disajikan kurang sesuai dengan karakteristik siswa SD di Provinsi Bengkulu. Kekurang-sesuaian ini disebabkan banyak wacana yang "asing" bagi siswa. Ke"asing"an tersebut karena siswa sama sekali tidak memiliki pengetahuan awal terkait materi yang disajikan. Menurut guru, permasalahan kesesuaian tema dapat diatasi dengan memperbanyak materi yang menyajikan lingkungan. Guru berharap bahan ajar menyajikan materi dengan mengaitkan lingkungan alam, sosial, dan budaya. Menurut guru, pengetahuan baru yang disajikan dengan berlandaskan pengetahuan yang sudah ada akan mudah dikonstruksi oleh siswa menjadi pengetahuan yang lebih besar.

Kelemahan lain buku ini menurut persepsi guru adalah materi pendukung pembelajaran. Materi pendukung pembelajaran dalam buku ini memiliki kekurangan dalam hal ketepatan prosedur dan rangsangan untuk giat belajar. Selain itu, teknik penyajian dalam buku ini memiliki kekurangan dalam hal keruntutan konsep.

Sistematika penyajian buku ini taat asas, memuat peta konsep, pendahuluan/apersepsi, isi yang memuat materi berbahasa dan bersastra lengkap dengan penjelasan konsep dan latihan, serta penutup yang terdiri atas evaluasi, rangkuman, dan refleksi. Uraian materi berbahasa dan bersastra disusun secara proporsional. Ilustrasi/gambar yang ditampilkan sesuai dengan materi yang disajikan.

b) Judul Buku Pengarang Penerbit Tahun terbit
Saya Senang Berbahasa Indonesia (SASEBI)

Hanif Nurcholis, Mafrukhi

Penerbit Erlangga

2006

Guru yang menggunakan buku ini dalam pembelajaran di kelas sebanyak 8 orang. Menurut persepsi guru, buku ini tingkat kelayakannya juga tergolong tinggi. Beberapa bagian juga perlu mendapatkan penyesuaian agar sesuai dengan konteks pembelajaran untuk siswa SD di Bengkulu. Berikut hasil lengkap persepsi guru terhadap buku "Bahasa Indonesia 4" yang terjaring melalui kuesioner yang disiapkan peneliti. 
Tabel 2 Penilaian Buku "Saya Senang Berbahasa Indonesia (SASEBI)" oleh Pengguna/Guru

\begin{tabular}{|c|c|c|c|c|}
\hline No & Sub Komponen & Detail & $\begin{array}{l}\text { Rerata } \\
\text { skor }\end{array}$ & Keterangan \\
\hline \multirow[t]{21}{*}{1.} & Kelayakan Isi & & & \\
\hline & A. Kesesuaian & 1) Keluasan Materi & 2,75 & Tinggi \\
\hline & Materi dengan & & & \\
\hline & Kebutuhan & & & \\
\hline & Pembelajaran & & & \\
\hline & & 2) Kedalaman materi & 2,38 & Tinggi \\
\hline & & 3) Pemilihan tema & 1,88 & Sedang \\
\hline & B. Keakuratan & 4) Ketepatan konsep & 3,38 & Sangat tinggi \\
\hline & Materi & & & \\
\hline & & 5) Keotentikan materi & 2,38 & Tinggi \\
\hline & & 6) Ketepatan prosedur & 2,13 & Tinggi \\
\hline & C. Materi & 7) $\quad$ Kesesuaian dengan & 2,88 & Tinggi \\
\hline & Pendukung & perkembangan ilmu & & \\
\hline & Pembelajaran & & & \\
\hline & & 8) Kemutakhiran wacana & 2,38 & Tinggi \\
\hline & & 9) Merangsang keingintahuan & 1,75 & Sedang \\
\hline & & 10) Keberagaman sosial dan & 2,00 & Sedang \\
\hline & & budaya & & \\
\hline & & 11) Ketersajian lingkungan & 1,38 & Rendah \\
\hline & & 12) Kecakapan hidup & 1,75 & Sedang \\
\hline & & $\begin{array}{l}\text { 13) Kecintaan terhadap bahasa } \\
\text { Indonesia }\end{array}$ & 3,50 & Sangat tinggi \\
\hline \multirow[t]{13}{*}{2.} & Kelayakan Penyajian & & & \\
\hline & A. Teknik Penyajian & 1) Konsistensi sistematika & 3,25 & Sangat tinggi \\
\hline & & 2) Keseimbangan antarbab & 2,50 & Tinggi \\
\hline & & 3) Keruntutan konsep & 2,50 & Tinggi \\
\hline & & 4) Kesesuaian/ ketepatan & 3,63 & Sangat tinggi \\
\hline & B. Penvaijan Bahan & $\begin{array}{l}\text { llustrasi dengan materı } \\
\text { 5) Berpusat pada peserta didik }\end{array}$ & 1,38 & Rendah \\
\hline & Ajar & & & \\
\hline & & $\begin{array}{l}\text { 6) Membangkitkan kemandirian } \\
\text { belajar }\end{array}$ & 2,00 & Sedang \\
\hline & & 7) Mengembangkan prakarsa, & 1,88 & Sedang \\
\hline & & $\begin{array}{l}\text { kreativitas, dan cara berpikir } \\
\text { kritis peserta didik }\end{array}$ & & \\
\hline & & 8) Mengembangkan kemampuan & 2,38 & Sedang \\
\hline & & 9) Metode pembelajaran tematis & 2,25 & Sedang \\
\hline & & 10) Variasi penyajian & 2,75 & Tinggi \\
\hline \multirow[t]{10}{*}{3.} & Kelayakan Bahasa & & & \\
\hline & A. Kesesuaian & 1) Kesesuaian dengan tingkat & 2,63 & Tinggi \\
\hline & Dengan Tingkat & perkembangan kognitif peserta & & \\
\hline & Perkembangan & didik & & \\
\hline & Peserta Didik & & & \\
\hline & & $\begin{array}{l}\text { 2) Kesesuaian dengan tingkat } \\
\text { perkembangan } \\
\text { siswa }\end{array}$ & 3,13 & Tinggi \\
\hline & B. Komunikatif & $\begin{array}{l}\text { 3) Keterbacaan pesan oleh } \\
\text { peserta didik }\end{array}$ & 2,38 & Sedang \\
\hline & & 4) Ketepatan kaidah bahasa & 3,50 & Sangat tinggi \\
\hline & C. Keruntutan dan & 5) Keruntutan makna dalam & 2,75 & Tinggi \\
\hline & Kesatuan Gagasan & $\begin{array}{l}\text { bagian/bab/ subbab/paragraf/ } \\
\text { kalimat }\end{array}$ & & \\
\hline
\end{tabular}




\begin{tabular}{lllll}
\hline $\begin{array}{l}\text { No } \\
\text { Sub Komponen }\end{array}$ & Detail & $\begin{array}{l}\text { Rerata } \\
\text { skor }\end{array}$ & Keterangan \\
\hline & $\begin{array}{l}\text { 6) Ketertautan makna antar } \\
\text { bagian/bab/ } \\
\text { kalimat }\end{array}$ & 2,75 & Tinggi \\
& & & \\
\hline & & 3,75 & Sangat tinggi \\
\hline 4. Kelayakan Perwajahan & 1) Tata letak & 3,75 & Sangat tinggi \\
\hline $\begin{array}{l}\text { A. Tata Letak Isi } \\
\text { Buku }\end{array}$ & 2) Penggunaan Ilustrasi & 3,63 & Sangat tinggi \\
\hline $\begin{array}{l}\text { B. Tipografi Isi } \\
\text { Buku }\end{array}$ & 3) Tipografi & & \\
\hline
\end{tabular}

Tabel 2 juga memperlihatkan bahwa secara keseluruhan, buku teks pelajaran bahasa Indonesia yang berjudul "Saya Senang Berbahasa Indonesia (SASEBI)" yang dikarang oleh Hanif Nurcholis dan Mafrukhi ini menurut persepsi guru tingkat kelayakannya tergolong tinggi.

Komponen isi yang terdapat dalam buku ini sesuai mendukung kurikulum yang digunakan saat pembelajaran dilakukan. Kelemahan buku ini menurut persepsi guru pengguna di Provinsi Bengkulu juga pada pilihan tema dan ketersajian lingkungan. Menurut guru, tema yang disajikan kurang sesuai dengan karakteristik siswa SD di Provinsi Bengkulu. Kekurang-sesuaian materi yang disajikan tidak akrab dengan pengetahuan siswa. Siswa tidak memiliki pengetahuan awal terkait materi yang disajikan. Menurut guru, permasalahan kesesuaian tema dapat diatasi dengan memperbanyak materi yang menyajikan lingkungan. Guru berharap bahan ajar menyajikan materi dengan mengaitkan lingkungan alam, sosial, dan budaya. Menurut guru, pengetahuan baru yang disajikan dengan berlandaskan pengetahuan yang sudah ada akan mudah dikonstruksi oleh siswa menjadi pengetahuan yang lebih besar.

Kelemahan lain buku ini menurut persepsi guru adalah penyajian materi pendukung pembelajaran. Materi yang disajikan tidak berpusat pada siswa. Akibatnya, siswa tidak terdorong untuk giat belajar secara mandiri. Materi pendukung pembelajaran dalam buku ini juga memiliki kekurangan dalam hal ketepatan prosedur dan ranngsangan untuk giat belajar. Selain itu, teknik penyajian dalam buku ini memiliki kekurangan dalam hal keruntutan konsep.

Sistematika penyajian buku ini taat asas, memuat peta konsep, pendahuluan/apersepsi, isi yang memuat materi berbahasa dan bersastra lengkap dengan penjelasan konsep dan latihan, serta penutup yang terdiri atas evaluasi, rangkuman, dan refleksi. Uraian materi berbahasa dan bersastra disusun secara proporsional. Ilustrasi/gambar yang ditampilkan sesuai dengan materi yang disajikan.

c) Judul Buku

Pengarang

Penerbit

Tahun terbit
Gemar Berbahasa Indonesia 4

Karsidi, Nafron Hasyim

Tiga Serangkai Solo

2006

Guru yang menggunakan buku ini dalam pembelajaran di kelas sebanyak 7 orang. Buku ini menurut persepsi guru tingkat kelayakannya juga tergolong tinggi, namun sama dengan dua buku yang dianalisis sebelumnya, perlu penyesuaian agar dapat digunakan dalam pembelajaran dan sesuai dengan konteks pembelajaran untuk siswa. Berikut ini hasil lengkap persepsi guru terhadap buku "Gemar Berbahasa Indonesia 4". 
Tabel 3 Penilaian Buku “Gemar Berbahasa Indonesia 4" oleh Guru

\begin{tabular}{|c|c|c|c|c|}
\hline No & Sub Komponen & Detail & $\begin{array}{l}\text { Rerata } \\
\text { Skor }\end{array}$ & Keterangan \\
\hline \multirow[t]{14}{*}{1.} & Kelayakan Isi & & & \\
\hline & $\begin{array}{lr}\text { A. } & \text { Kesesuaian } \\
\text { Materi } & \text { dengan } \\
\text { Kebutuhan } & \\
\text { Pembelajaran } & \\
\end{array}$ & 1) Keluasan Materi & 2,86 & Tinggi \\
\hline & & 2) Kedalaman materi & 2,43 & Tinggi \\
\hline & & 3) Pemilihan tema & 1,86 & Sedang \\
\hline & $\begin{array}{ll}\text { B. } & \text { Keakuratan } \\
\text { Materi } & \\
\end{array}$ & 4) Ketepatan konsep & 3,29 & Sangat tinggi \\
\hline & & 5) Keotentikan materi & 2,57 & Tinggi \\
\hline & & 6) Ketepatan prosedur & 2,43 & Tinggi \\
\hline & $\begin{array}{l}\text { C. Materi } \\
\text { Pendukung } \\
\text { Pembelajaran } \\
\end{array}$ & 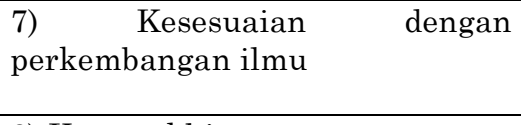 & 3,14 & Tinggi \\
\hline & & 8) Kemutakhiran wacana & 2,43 & Tinggi \\
\hline & & $\begin{array}{l}\text { 9) Merangsang keingintahuan } \\
\text { dan giat untuk belajar }\end{array}$ & 2,00 & Sedang \\
\hline & & $\begin{array}{l}\text { 10) Keberagaman sosial dan } \\
\text { budaya }\end{array}$ & 2,43 & Tinggi \\
\hline & & 11) Ketersajian lingkungan & 1,71 & Sedang \\
\hline & & 12) Kecakapan hidup & 1,71 & Sedang \\
\hline & & $\begin{array}{l}\text { 13) Kecintaan terhadap bahasa } \\
\text { Indonesia }\end{array}$ & 3,71 & Sangat tinggi \\
\hline \multirow[t]{11}{*}{2.} & Kelayakan Penyajian & & & \\
\hline & A. Teknik Penyajian & 1) Konsistensi sistematika & 3,43 & Sangat tinggi \\
\hline & & 2) Keseimbangan antarbab & 2,57 & Tinggi \\
\hline & & 3) Keruntutan konsep & 2,71 & Tinggi \\
\hline & & $\begin{array}{l}\text { 4) Kesesuaian/ ketepatan } \\
\text { ilustrasi dengan materi }\end{array}$ & 3,29 & Sangat tinggi \\
\hline & $\begin{array}{l}\text { B. Penyajian Bahan } \\
\text { Ajar }\end{array}$ & 5) Berpusat pada peserta didik & 2,14 & Sedang \\
\hline & & $\begin{array}{l}\text { 6) Membangkitkan kemandirian } \\
\text { belajar }\end{array}$ & 1,86 & Sedang \\
\hline & & $\begin{array}{l}\text { 7) Mengembangkan prakarsa, } \\
\text { kreativitas, dan cara berpikir } \\
\text { kritis peserta didik }\end{array}$ & 2,00 & Sedang \\
\hline & & $\begin{array}{l}\text { 8) Mengembangkan kemampuan } \\
\text { untuk refleksi/evaluasi diri }\end{array}$ & 2,57 & Tinggi \\
\hline & & 9) Metode pembelajaran tematis & 2,57 & Tinggi \\
\hline & & 10) Variasi penyajian & 2,57 & Tinggi \\
\hline \multirow[t]{6}{*}{3.} & Kelayakan Bahasa & & & \\
\hline & $\begin{array}{lr}\text { A. Kesesuaian } \\
\text { Dengan Tingkat } \\
\text { Perkembangan } \\
\text { Peserta Didik } \\
\end{array}$ & $\begin{array}{l}\text { 1) Kesesuaian dengan tingkat } \\
\text { perkembangan kognitif peserta } \\
\text { didik }\end{array}$ & 3,43 & Sangat tinggi \\
\hline & & $\begin{array}{ll}2 \text { K) Kesesuaian dengan tingkat } \\
\text { perkembangan } & \text { sosial-emosional } \\
\text { siswa } & \\
\end{array}$ & 3,43 & Sangat tinggi \\
\hline & B. Komunikatif & $\begin{array}{l}\text { 3) Keterbacaan pesan oleh peserta } \\
\text { didik }\end{array}$ & 2,57 & Tinggi \\
\hline & & 4) Ketepatan kaidah bahasa & 3,57 & Sangat tinggi \\
\hline & $\begin{array}{l}\text { C. Keruntutan dan } \\
\text { Kesatuan Gagasan }\end{array}$ & $\begin{array}{l}\text { 5) Keruntutan makna dalam } \\
\text { bagian/bab/subbab/paragraf/ } \\
\text { kalimat }\end{array}$ & 2,57 & Tinggi \\
\hline
\end{tabular}




\begin{tabular}{|c|c|c|c|c|}
\hline No & Sub Komponen & Detail & $\begin{array}{l}\text { Rerata } \\
\text { Skor }\end{array}$ & Keterangan \\
\hline & & $\begin{array}{l}\text { 6) Ketertautan makna antar } \\
\text { bagian/bab/ } \\
\text { kalimat }\end{array}$ & 2,86 & Tinggi \\
\hline \multirow[t]{4}{*}{4.} & Kelayakan Perwajaha & & & \\
\hline & $\begin{array}{l}\text { A. Tata Letak Isi } \\
\text { Buku }\end{array}$ & 1) Tata letak & 3,71 & Sangat tinggi \\
\hline & & 2) Penggunaan Ilustrasi & 3,43 & Sangat tinggi \\
\hline & $\begin{array}{l}\text { B. Tipografi Isi } \\
\text { Buku }\end{array}$ & 3) Tipografi & 4,00 & Sangat tinggi \\
\hline
\end{tabular}

Tabel 12 di atas juga memperlihatkan bahwa secara keseluruhan, buku teks pelajaran bahasa Indonesia yang berjudul "Gemar Berbahasa Indonesia 4" yang dikarang oleh Karsidi dan Nafron Hasyim ini menurut persepsi guru tingkat kelayakannya tergolong tinggi. Bahkan secara umum, buku ini nilai kelayakannya berdasarkan persepsi guru tergolong lebih tinggi dibanding dua buu teks yang dianalisis lebih dulu.

Komponen isi yang terdapat dalam buku ini juga sesuai dengan kurikulum yang digunakan saat pembelajaran dilakukan. Kelemahan buku ini masih sama dengan buku sebelumnya, juga pada pilihan tema dan ketersajian lingkungan. Menurut guru, tema yang disajikan kurang sesuai dengan karakteristik siswa SD di Provinsi Bengkulu. Kekurang-sesuaian materi yang disajikan tidak akrab dengan pengetahuan siswa. Siswa tidak memiliki pengetahuan awal terkait materi yang disajikan. Menurut guru, permasalahan kesesuaian tema dapat diatasi dengan memperbanyak materi yang menyajikan lingkungan. Guru berharap bahan ajar menyajikan materi dengan mengaitkan lingkungan alam, sosial, dan budaya. Menurut guru, pengetahuan baru yang disajikan dengan berlandaskan pengetahuan yang sudah ada akan mudah dikonstruksi oleh siswa menjadi pengetahuan yang lebih besar.

Kelemahan lain menurut persepsi guru adalah penyajian materi pendukung pembelajaran. Materi yang disajikan tidak berpusat pada siswa. Akibatnya, siswa tidak terdorong untuk giat belajar secara mandiri. Materi pendukung pembelajaran dalam buku ini juga memiliki kekurangan dalam hal ketepatan prosedur dan rangsangan untuk giat belajar. Selain itu, teknik penyajian dalam buku ini memiliki kekurangan dalam hal keruntutan konsep.

Sistematika penyajian buku ini taat asas, memuat peta konsep, pendahuluan/apersepsi, isi yang memuat materi berbahasa dan bersastra lengkap dengan penjelasan konsep dan latihan, serta penutup yang terdiri atas evaluasi, rangkuman, dan refleksi. Uraian materi berbahasa dan bersastra disusun secara proporsional. Ilustrasi/gambar yang ditampilkan sesuai dengan materi yang disajikan.

\section{Pembahasan}

Kemampuan membaca siswa sekolah dasar di Indonesia masih tergolong rendah. Kesimpulan tersebut hampir selalu muncul dalam semua penelitian tentang kemampuan membaca. Rendahnya kemampuan membaca siswa SD di Indonesia tersebut, ditengarai disebabkan oleh beberapa faktor. Salah satu faktor penentu dominan rendahnya keterampilan membaca siswa pendidikan dasar adalah permasalahan bahan ajar membaca yang ada.

Permasalahan terkait bahan ajar meliputi: (1) masalah mutu bahan ajar; dan (2) masalah ketersediaan. Permasalahan rendahnya mutu bahan ajar telah diteliti oleh Pusat Perbukuan Nasional. Sekitar 50\% lebih dari 152 buku pelajaran sekolah dasar, termasuk buku pelajaran bahasa Indonesia, yang beredar pada tahun 2011 tidak 
memenuhi standar mutu dalam hal isi buku, bahasa, dan grafika. (Suryaman \& Kusmana, 2004) Tidak terpenuhinya kelayakan buku pelajaran dimaksud, terkait dengan: pengolahan kurikulum, kebenaran ilmu, kreativitas berpikir, pengembangan etika profesional, data kritis, keterbacaan, dan lainnya masih diabaikan.

Di Provinsi Bengkulu, guru lebih memilih buku teks pelajaran sekolah dasar yang tersedia di pasaran. Pilihan ini beresiko, karena menurut kajian peneliti, tingkat keterbacaan buku teks yang digunakan tidak terlalu tinggi, yaitu 3,85 dalam skala maksimal 5,00. Seperti diketahui, keterbacaan buku teks bergantung pada keterpahaman kosakata, kalimat, paragraf dan jenis bacaan yang digunakan; kemenarikan penyajian buku tersebut; dan kemudahan menggunakan sistematika penyajian materi.

Keterpahaman kosakata dalam buku teks pelajaran ditentukan oleh seringnya kosakata tersebut didengar dan sudah dikenal oleh siswa. Keterpahaman kalimat dalam buku teks pelajaran ditentukan oleh tingkat keintiman dan kesederhanaan kalimat tersebut bagi siswa, jika kalimat-kalimat dalam buku teks sudah sering dikenal oleh siswa atau disajikan dengan susunan yang sederhana maka keterbacaan buku teks pelajaran tersebut semakin tinggi. Kelemahan umum buku teks pelajaran bahasa Indonesia yang digunakan dalam pembelajaran membaca di kelas IV SD di provinsi Bengkulu adalah keintiman materi yang disajikan. Materi yang disajikan dalam buku teks yang dipasarkan secara nasional itu, tidak kontekstual untuk pembelajaran siswa SD di Bengkulu. Kandungan materi (terutama yang berbentuk wacana) banyak yang dipahami siswa, karena tidak didukung pengetahuan awal yang cukup tentang itu.

Kemenarikan penyajian buku-buku teks pelajaran yang digunakan guru umumnya tinggi, karena menggunakan pewarnaan, gambar dan/atau ilustrasi yang memperjelas isi materi yang disajikan dan menggunakan huruf atau bacaan yang jelas dan terbaca. Buku teks pelajaran yang menggunakan bahasa yang mudah dipahami, menggunakan jilid atau gambar berwarna, menggunakan gambar dan ilustrasi yang dapat memperjelas isi, serta menggunakan huruf yang terbaca dan jelas, memiliki daya tarik dan menentukan tingginya tingkat keterbacaan buku tersebut.

Pada sisi lain, ketersediaan bahan ajar secara fisik di sekolah masih jauh dari cukup. Rasio ketersediaan bulu teks, menurut ketentuan Badan Standar Nasional Pendidikan (BSNP) adalah 1: 1, artinya jumlah siswa berbanding lurus dengan jumlah ketersediaan buku teks. Setiap satu siswa menggunakan satu buku teks pelajaran sebagai bahan ajar. Selain buku teks pelajaran, sekolah juga harus menyediakan buku penunjang/buku pengayaan sebagai bahan bacaan siswa.

Di Provinsi Bengkulu, upaya pemenuhan bahan ajar sebagai penunjang pembelajaran pada jenjang pendidikan dasar, masih jauh dari kelayakan. Jumlah lembaga sekolah dasar di Provinsi Bengkulu adalah 1.278 sekolah. Dari jumlah tersebut, sekolah yang memiliki perpustakaan hanya 557 sekolah. Perpustakaan yang ada juga masih jauh dari memadai, baik dari jumlah koleksi buku, kondisi koleksi buku, dan manajemen pengelolaannya

Sementara itu, berdasarkan observasi lapangan, diperoleh data bahwa rasio buku siswa, masih belum ideal. Di sekolah-sekolah yang berlokasi di wilayah perkotaan, rasio buku berbanding siswa 1: 1 terpenuhi, namun di wilayah perdesaan tidak semua siswa memiliki buku teks pelajaran. Bahkan di salah satu SD tempat peneliti melakukan observasi, yaitu SDN 03 Topos di Kab. Lebong, didapati seluruh siswa kelas IV tidak memiliki buku Bahasa Indonesia. Dengan terpaksa, guru hanya mengandalkan metode ceramah dan memanfaatkan papan tulis untuk menyalin buku teks sebagai bahan ajar membaca. 


\section{Simpulan}

Setelah melakukan analisis terhadap data persepsi guru terhadap buku teks bahasa Indonesia, yang digunakan sebagai bahan ajar membaca, ternyata terdapat kemiripan hasil. Hasil analisis bahan ajar yang tersedia adalah sebagai berikut:

1) Semua buku teks bahasa Indonesia yang tersedia di pasaran, menurut persepsi guru pengguna, kelayakannya tergolong tinggi.

2) Kelemahan buku teks menurut persepsi guru meliputi:

a) Tema yang disajikan kurang sesuai dengan karakteristik siswa SD di provinsi Bengkulu.

b) Materi yang disajikan tidak memuat lingkungan siswa.

c) Materi yang disajikan tidak berpusat pada siswa.

d) Materi tidak merangsang siswa untuk giat belajar secara mandiri.

e) Konsep dalam buku-buku teks tersebut kurang runtut.

\section{Saran}

Saran yang dapat diberikan dari penelitian ini,

1. Peneliti berikut dapat mengeksplorasi lebih jauh kebutuhan bahan ajar untuk pembelajaran di SD secara kualitatif, sehingga kondisi spesifik yang diharapkan dapat digali.

2. Peneliti berikutnya dapat menggali topik-topik apa saja yang diharapkan dikembangkan sebagai bahan ajar membaca bagi siswa SD di Provinsi Bengkulu.

\section{Referensi}

Council on Economic Development. (2011). "High Literacy" and Language Art Curriculum. School Improvement in Maryland. Mariland: (CED). "High Literacy" and Language Art Curriculum. School Improvement in Maryland. (online). (http://www.mdk12.org/practices/ good_instruction/projectbetter/elangarts/ela-64-66.html) diakses pada tanggal 24 Desember 2011. Diambil kembali dari http://www.mdk12.org/practices/ good_instruction/projectbetter/elangarts/ela-64-66.html

Graves, D. (2011). Emergent Reading and Writing Connection. School Improvement in Maryland. Diambil kembali dari http://www.mdk12.org/practices/good_ instruction/projectbetter/ elangarts/ela-97-99.html

Pinnell, G. S., \& Matlin, M. L. (1990). Teachers and Research Language Learning in the Classroom. Newark: Intl Literacy Assn.

Resnick, L. B. (1987). Education and Learning to Think. Washington D.C.: National Academy Press.

Salinger, T. (2001). Literate Environment. School Improvement in Maryland. . Diambil kembali dari Council on Economic Development (CED): http://www.mdk12.org/practices/good_instruction/projectb etter/elangarts/ela62-63.html

Suparno, Kurniawan, K., \& Widaryanto, B. (2016). Proses Belajar Mengajar Mata Peljaran Bahasa Indonesia pada Jenjang Pendidikan Dasar. Jakarta: Badan Penelitian dan Pengembangan Kemendiknas.

Suryaman, M., \& Kusmana, S. (2004, 05 17). Mutu Buku Pelajaran Sekolah. Pikiranrakyat.com, hal. 8.

Trianto, A. (Juli 1998,). Kajian Buku Teks Bahasa Indonesia di SD. Jurnal Penelitian UNIB, IV(12), 96-100. 